\title{
DAYA ANTIBAKTERI TEPUNG CACING TANAH (Lumbricus rubellus) TERHADAP PERTUMBUHAN BAKTERI Vibrio harveyi SECARA IN VITRO
}

\section{ANTIBACTERIAL ACTIVITY OF EARTHWORM POWDER (Lumbricus rubellus) TO Vibrio harveyi GROWTH'S IN VITRO}

\author{
Ekasari, Wahju Tjahjaningsih dan Yudi Cahyoko \\ Fakultas Perikanan dan Kelautan Universitas Airlangga \\ Kampus C Mulyorejo - Surabaya, 60115 Telp. 031-5911451
}

\begin{abstract}
Vibrio harveyi is the most common pathogenic agent of Penaeus monodon and causing large economic losses to the shrimp farming industry. Antibiotic has been used as the diseases treatment, but it has been banned due to the side effects. This problem was required an alternative solution by using natural material, such as earthworm powder (L. rubellus).

This research was conducted to know the bacterial growth inhibition $V$. harveyi by using earthworm powder (L. rubellus). The research method is experimental and data analysis done descriptively. Inhibition of $V$. harveyi growth was tested using disc diffusion method. Earthworm powder concentrations are $0,25,50,75,100 \%(\mathrm{w} / \mathrm{v})$ and chloramphenicol disc $(30 \mu \mathrm{g})$, each treatment was repeated three times. The main parameter observed was the size of diameter inhibition zone (mm) which formed around the disc paper after incubation within 24 hours. The data analysis was done descriptively by comparing sensitivity level each treatment.

Results showed that earthworms powder (L. rubellus) from the lowest concentration $(25 \% \mathrm{w} / \mathrm{v})$ to the highest concentration $(100 \% \mathrm{w} / \mathrm{v})$ were not able to inhibit $V$. harveyi growth.
\end{abstract}

Keywords : antibacterial activity, earthworm powder (L. rubellus), V. harveyi

\section{Pendahuluan}

Produksi udang windu (Penaues monodon) yang merupakan komoditas ekspor dengan nilai ekonomi tinggi sejak awal tahun 1990-an terus mengalami penurunan (Umar, 2009). Salah satu penyebab turunnya produksi udang windu di Indonesia adalah adanya serangan bakteri pathogen (Izzati, 2007) salah satunya Vibrio harveyi. Bakteri ini umumnya menyerang larva udang pada stadia zoea, mysis dan awal pasca larva dan serangan ini umumnya terjadi sepanjang tahun yang puncaknya biasa terjadi pada bulan Juli sampai September (Prayitno, 2005).

Penanganan yang umum dilakukan untuk mengatasi vibriosis dengan menggunakan antibiotika (Rukyani, 1999). Namun penggunaan antibiotika dapat menimbulkan masalah baru seperti resistensi bakteri, retensi bahan toksik dan residu bagi tubuh konsumen, yang pada akhirnya berdampak pada penolakan hasil perikanan (Maryani dkk., 2002). Permasalahan ini menyebabkan perlunya solusi alternatif penanganan vibriosis tanpa menggunakan antibiotika. Penelitian ini mencoba untuk menemukan alternatif penggunaan bahan antibakteri yang diperoleh dari bahan alami, yaitu tepung cacing tanah $(L$. rubellus) yang diharapkan dapat menghambat pertumbuhan bakteri $V$. harveyi secara in vitro.

Tepung cacing tanah (L. rubellus) mengandung zat aktif antibakteri (Julendra, 2003), enzim lysozyme, agglutinin, faktor litik (Puwaningroom, 2010) dan kandungan protein yang cukup tinggi, yaitu sebesar 64-76 \% dari bahan kering (BK) (Palungkun, 2008) serta mengandung asam amino prolin sekitar $15 \%$ dari 62 asam amino (Cho et al., 1998). Aktivitas antibakteri L. rubellus berasal dari Lumbricin I yang merupakan senyawa peptida antimikroba yang berhasil diisolasi dan dikarakterisasi dari cacing tanah (L. rubellus) (Cho et al., 1998). Cho et al. (1998) menyatakan bahwa hasil uji in vitro menunjukkan Lumbricin I mempunyai aktivitas antimikroba berspektrum luas, yaitu menghambat bakteri Gram positif, bakteri Gram negatif dan jamur.

Penelitian ini bertujuan untuk mengetahui daya antibakteri tepung cacing tanah (L. rubellus) terhadap pertumbuhan bakteri $V$. harveyi yang tampak dari diameter zona hambat, sehingga nantinya dapat memberikan informasi tentang daya antibakteri tepung cacing tanah (L. rubellus) terhadap pertumbuhan bakteri $V$. harveyi secara in vitro. 


\section{Metodologi}

Penelitian ini dilakukan di Balai Karantina Ikan Kelas I Juanda, Surabaya, pada bulan Juni - Juli 2011. Adapun bahan penelitian yang digunakan adalah isolat $V$. harveyi, yang diperoleh dari Balai Besar Pengembangan Budidaya Air Payau Jepara. Cacing tanah diperoleh dari penjual cacing di sepanjang Jalan Jagir, Surabaya. Media Nutrient Agar (NA) (ditambah $\mathrm{NaCl} 2 \%$ ), akuadest steril, kertas disk, $\mathrm{NaCl}$ fisiologis, standar Mc Farland 0.5, kloramfenikol disk $(30 \mu \mathrm{g})$, reagen uji pewarnaan Gram (Gram A, B, C, D), paper oxidase, $\mathrm{H}_{2} \mathrm{O}_{2} 3 \%$, Oxidative- Fermentative (OF) test medium, paraffin, Tryptic Soy Iron Agar (TSIA), Motility Indol Ornithin (MIO) test medium, Simmon's Citrat medium, Urease medium, Arginin medium, Gelatin medium, Phenol Red Broth Sugar,Lysine Iron Agar (LIA), Thiosulphate Citrat Bilesalt Sucrose Agar (TCBSA), reagen uji MRVP, reagen Kovacs.

Peralatan penelitian yang digunakan meliputi blender, timbangan, cawan petri, tabung reaksi, rak tabung reaksi, vortex, pembakar bunsen, ose, needle, mikroskop, object glass, beaker glass, erlenmeyer, autoclave, pinset, mikropipet, pipetip, inkubator, spatel bengkok, hot plate stirrer, jangka sorong.

Metode yang digunakan dalam penelitian ini adalah metode eksperimental yang dilakukan secara in vitro dengan menggunakan uji sensitivitas metode difusi disk dengan mencari konsentrasi hambat minimal larutan antibakteri yang dapat menghambat pertumbuhan bakteri $V$. harveyi. Adapun pelaksanaan penelitian ini adalah sebagai berikut:

a. Pembuatan Tepung Cacing Tanah

Cacing tanah yang digunakan diidentifikasi terlebih dahulu agar cacing yang diproses benar-benar spesies L. rubellus. Proses pembuatan tepung cacing tanah dilakukan dengan menggunakan metode Singgih (2006) dalam Adam (2007). Cacing tanah dibersihkan dari tanah dan kotoran lainnya yang menempel dengan menggunakan air yang mengalir. Cacing tanah kemudian dikeringkan dengan cara dijemur selama 1-2 hari hingga kering. Cacing yang telah kering selanjutnya dihaluskan dengan blender hingga menjadi tepung cacing tanah.

b. Identifikasi Bakteri

Sebagai langkah awal, dilakukan peremajaan terhadap koloni bakteri $V$. harveyi dengan cara ditanam pada Thiosulphate Citrat Bilesalt Sucrose Agar (TCBSA) sebagai media selektifnya, kemudian dilakukan pewarnaan Gram dan uji biokimia untuk memastikan bahwa isolat yang digunakan benar- benar murni $V$. harveyi

c. Penyiapan Suspensi Bakteri

Pembuatan suspensi bakteri dilakukan dengan cara melakukan pengenceran bertingkat hingga diperoleh suspensi bakteri dengan tingkat kekeruhan yang setara dengan standar Mc Farland 0.5 (1X10 $0^{7}$ sampai $\left.1 \times 10^{8} \mathrm{CFU} / \mathrm{ml}\right)$ (Quelab, 2005). Penggunaan Mc Farland 0.5 $\left(1 \mathrm{X} 10^{7}\right.$ sampai $\left.1 \times 10^{8} \mathrm{CFU} / \mathrm{ml}\right)$ sebagai standar dikarenakan bakteri $V$. harveyi mengakibatkan infeksi pada post larva dan juvenil $P$. monodon dengan kepadatan bakteri $10^{2}-10^{3} \mathrm{CFU} / \mathrm{ml}$ dan pada post larva dan juvenil $P$. vannamei dengan kepadatan bakteri $10^{6}-10^{7} \mathrm{CFU} / \mathrm{ml}$ (Saulnier et al., 2000).

Pengenceran bertingkat dilakukan dengan cara menyiapkan empat buah tabung reaksi, tabung pertama diisi dengan $\mathrm{NaCl}$ fisiologis sebanyak $10 \mathrm{ml}$, sedangkan tabung kedua sampai keempat diisi dengan $\mathrm{NaCl}$ fisiologis sebanyak $9 \mathrm{ml}$. Kemudian koloni bakteri pada media (NA ditambah $\mathrm{NaCl} 2 \%$ ) diambil sebanyak 4 sampai 5 koloni, kemudian dicampur dengan $10 \mathrm{ml} \mathrm{NaCl}$ fisologis dan dihomogenkan dengan cara divortex. Kemudian dilakukan pengenceran bertingkat dengan menambahkan $1 \mathrm{ml}$ suspensi bakteri dari tabung 1 ke tabung 2, suspensi kemudian dihomogenkan dengan cara divortex, demikian seterusnya hingga tabung keempat. Kemudian keempat tabung tersebut disetarakan tingkat kekeruhannya dengan standar Mc Farland 0.5.

d. Penyiapan Larutan Tepung Cacing Tanah ( $L$. rubellus)

Tepung cacing tanah (L. rubellus) yang akan digunakan dalam penelitian ini dilarutkan dalam air (Purwaningroom, 2010) karena bahan aktif yang terkandung dalam tepung cacing tanah, Lumbricin , merupakan asam amino yang kaya akan prolin yang bersifat larut dalam air (Gold Biotechnology, 2009). Konsentrasi tepung cacing tanah (L. rubellus) yang akan diuji cobakan mengacu pada penelitian sebelumnya (Damayanti dkk, 2009; Julendra dan Sofyan, 2007) yaitu sebesar 0\%, 25\%, 50\%, $75 \%$ dan $100 \%$ (b/v). Dimana $\%$ b/v menyatakan jumlah gram zat dalam $100 \mathrm{ml}$ larutan, sebagai pelarut dapat digunakan air/ pelarut lain (Departemen Kesehatan, 1995).

Proses penyiapan larutan tepung cacing tanah dilakukan dengan cara sebagai berikut, sebanyak 5 tabung reaksi steril disiapkan dan diberi nomor satu sampai lima. Setiap tabung diisi dengan $1 \mathrm{ml}$ akuadest steril, kemudian ke dalam tabung nomor satu sampai lima secara 
berurutan ditambahkan tepung cacing tanah sebanyak $0 \mathrm{~g}, 0.25 \mathrm{~g}, 0.5 \mathrm{~g}, 0.75 \mathrm{~g}$ dan $1 \mathrm{~g}$. Kemudian campuran dihomogenkan dengan cara divortex, selanjutnya disentrifus dengan kecepatan $1000 \mathrm{rpm}$ selama 5 menit. Dari proses ini endapan tepung cacing tanah akan terpisah dengan supernatan, kemudian masingmasing supernatan dipindahkan ke tabung reaksi steril baru dengan menggunakan mikropipet.

e. Pengisian Kertas Disk

Kertas disk disterilkan terlebih dahulu dengan meletakkan kertas disk dalam cawan petri dan disterilkan dalam autoclave selama 1520 menit pada suhu $121^{\circ} \mathrm{C}$ (Windyaanita, 2006). Selanjutnya kertas disk yang telah disterilkan, dimasukkan ke dalam 5 tabung reaksi yang berisi supernatan tepung cacing tanah dengan konsentrasi berbeda yang telah disiapkan sebelumnya. Setiap tabung berisi tiga buah kertas disk, dan dibiarkan selama 15-20 menit agar zat aktif dalam supernatan tepung cacing tanah dapat meresap ke dalam kertas disk (Windyaanita, 2006).

Untuk perlakuan kontrol positif digunakan kertas disk yang telah berisi antibiotika kloramfenikol, karena kloramfenikol memiliki sensitivitas yang sangat tinggi terhadap $V$. harveyi (Uma et al., 2005), dimana pada dosis $30 \mu \mathrm{g} /$ kertas disk mampu menghasilkan diameter zona hambat sebesar 25$31 \mathrm{~mm}$ (Rattanachuay, et al., 2010).

f. Pengujian Aktivitas Antibakteri dengan Metode Difusi Disk

Sebanyak $200 \mu \mathrm{L}$ suspensi bakteri $V$. harveyi yang telah disetarakan tingkat kekeruhannya dengan standar Mc Farland 0.5, diinokulasikan ke dalam cawan petri yang berisi media NA (ditambah $\mathrm{NaCl} 2 \%$ ) yang telah memadat, kemudian suspensi bakteri diratakan dengan spatel bengkok dan dibiarkan selama 15-20 menit agar bakteri dapat meresap dengan baik (Windyaanita, 2006). Kertas disk yang telah disiapkan sebelumnya, diletakkan di atas permukaan media dengan pinset steril dan dibiarkan selama 15-20 menit agar bahan antibakteri dalam kertas disk tersebut dapat berdifusi dengan baik ke dalam media sebelum pertumbuhan bakteri berlangsung (Windyaanita, 2006). Kemudian cawan petri diinkubasi pada suhu ruang selama 24 jam.

Variabel yang diamati dalam penelitian ini adalah ukuran diameter zona hambat (zona jernih) (mm) yang terbentuk di sekitar kertas disk yang diukur pada jam ke-24 setelah inkubasi dengan menggunakan jangka sorong (Dewi, 2010). Variabel bebas berupa konsentrasi tepung cacing tanah yaitu $0,25,50$, 75, dan $100 \%$ (b/v). Variabel terkontrol berupa suhu, lama inkubasi dan volume suspensi dan konsentrasi bakteri yang diberikan dalam setiap cawan petri.

Data hasil penelitian berupa diameter zona hambat pertumbuhan bakteri $V$. harveyi oleh antibakteri tepung cacing tanah ( $L$. rubellus) dan kloramfenikol. Data tersebut disajikan secara deskriptif .

\section{Hasil dan Pembahasan \\ Setelah dilakukan uji identifikasi terhadap isolat bakteri yang digunakan, diketahui bahwa isolat tersebut merupakan bakteri Vibrio harveyi. Hasil zona hambat pertumbuhan bakteri $V$. harveyi dengan menggunakan tepung cacing tanah (L. rubellus) sebagai antibiotika alami dan kloramfenikol sebagai antibiotika kimiawi dapat dilihat pada Tabel 1.}

Tabel 1. Zona Hambat yang Terbentuk dibandingkan dengan Standar Umum Antibiotika Kloramfenikol

\begin{tabular}{|c|c|c|c|c|}
\hline \multirow{2}{*}{$\begin{array}{c}\text { Konsentrasi Tepung } \\
\text { Cacing Tanah } \\
\text { (L. rubellus) }\end{array}$} & $\begin{array}{c}\text { Diameter Zona } \\
\text { Hambat (mm) }\end{array}$ & \multicolumn{3}{|c|}{ Kriteria Diameter Zona Hambat Antibiotika } \\
\cline { 3 - 5 } & & $\begin{array}{c}\text { Tidak Peka } \\
(\leq 12 \mathrm{~mm})\end{array}$ & $\begin{array}{c}\text { Cukup Peka } \\
(13-17 \mathrm{~mm})\end{array}$ & $\begin{array}{c}\text { Sangat Peka } \\
(\geq 18 \mathrm{~mm})\end{array}$ \\
\hline $100 \%$ & 0 & $\sqrt{ }$ & - & - \\
$75 \%$ & 0 & $\sqrt{ }$ & - & - \\
$50 \%$ & 0 & $\sqrt{ }$ & - & - \\
$25 \%$ & 0 & $\sqrt{ }$ & - & - \\
$0 \%$ & 0 & $\sqrt{ }$ & - & $\sqrt{ }$ \\
\hline
\end{tabular}


Berdasarkan hasil penelitian yang telah dilakukan secara in vitro tentang daya antibakteri tepung cacing tanah (L. rubellus) terhadap bakteri $V$. harveyi, yang tercantum dalam Tabel 1, dapat diketahui bahwa tepung cacing tanah (L. rubellus) pada konsentrasi terendah $(25 \%)$ hingga konsentrasi tertinggi $(100 \%)$ tidak memiliki efektivitas dalam menghambat pertumbuhan bakteri $V$. harveyi. Kloramfenikol mempunyai efektivitas yang sangat peka dalam menghambat pertumbuhan bakteri $V$. harveyi, hal ini sesuai dengan pendapat Uma et al. (2005) dan Rattanachuay et al. (2010) yang menyatakan bahwa kloramfenikol memiliki sensitivitas yang sangat tinggi terhadap $V$. harveyi.

Hasil yang diperoleh dalam penelitian ini, berbeda dengan hasil penelitian sebelumnya yang menyatakan bahwa tepung cacing tanah (L. rubellus) secara in vitro mampu menghambat pertumbuhan bakteri Escherichia coli (Julendra dan Sofyan, 2007), Salmonella pullorum (Damayanti dkk., 2009; Julendra, 2005), Salmonella typhi (Purwaningroom, 2010), serta penelitian secara in vivo mampu meningkatkan nilai kelulushidupan ikan lele dumbo (Clarias gariepinus) (Adam, 2007) dan ikan mas (Cyprinus carpio) (Asfanti, 2008) yang diinfeksi dengan Aeromonas hydrophylla.

Peneliti sebelumnya menyatakan bahwa tepung cacing tanah (L. rubellus) mampu menghambat pertumbuhan bakteri baik Gram positif maupun Gram negatif, dikarenakan tepung cacing tanah (L. rubellus) mengandung bahan aktif antibakteri lumbricin (Cho et al., 1998; Julendra dan Sofyan, 2007; Damayanti dkk., 2009 dan Julendra, 2005), enzim lysozime, aglutinin, dan faktor litik (Purwaningroom, 2010). Lumbricin, merupakan senyawa peptida antimikroba yang kaya akan asam amino prolin dari total 62 asam amino (15\% prolin dalam rasio molar dengan berat molekul $7231 \mathrm{Da})$. Lumbricin menunjukkan aktifitas antimikroba in vitro pada sejumlah besar mikroorganisme tanpa aktivitas hemolitik (Cho et al., 1998).

Mekanisme kerja lumbricin dalam menghambat pertumbuhan bakteri hingga saat ini masih belum diketahui secara pasti, namun tingginya kandungan prolin dalam lumbricin merupakan faktor yang tidak diragukan lagi sebagai salah satu faktor yang berperan dalam mekanisme kerja lumbricin sebagai suatu antimikroba (Cho et al., 1998). Dari beberapa peptida antimikroba yang juga mengandung asam amino prolin dalam jumlah tinggi, juga mempunyai mekanisme kerja dan spektrum yang berbeda-beda dalam menghambat pertumbuhan bakteri (Cho et al., 1998).
Terdapat suatu penyebab yang mengakibatkan tepung cacing tanah ( $L$. rubellus) tidak mampu menghambat pertumbuhan bakteri $V$. harveyi secara in vitro. Penyebab tersebut diduga karena bakteri $V$. harveyi resisten terhadap bahan aktif dalam tepung cacing tanah (L. rubellus) melalui beberapa mekanisme.

Yeaman and Yount (2003) menyatakan, salah satu mekanisme resistensi peptida antimikroba disebabkan karena adanya produk ekstraseluler yang dihasilkan oleh bakteri berupa enzim proteolitik seperti peptidase atau protease. Pendapat ini juga didukung oleh Whitelock et al. (1996) yang menyatakan bahwa beberapa bakteri memproduksi enzim proteolitik yang dapat mendegradasi peptida antimikroba sehingga menjadi resisten. $V$. harveyi merupakan bakteri yang juga mampu menghasilkan enzim protease (Sarkar et al., 2010), sehingga diduga bahwa tepung cacing tanah (L. rubellus) tidak mampu menghambat pertumbuhan bakteri $V$. harveyi. Hal ini disebabkan sebelum melakukan aktivitas antimikroba, bahan aktif dalam tepung cacing tanah (L. rubellus) yang berupa senyawa peptida telah terdegradasi terlebih dahulu oleh enzim protease yang diproduksi oleh $V$. harveyi.

Selain itu, terdapat dugaan lain yang menyebabkan tepung cacing tanah (L. rubellus) tidak mampu menghambat pertumbuhan bakteri V. harveyi, yaitu asam amino prolin yang terkandung dalam bahan aktif tepung cacing tanah (lumbricin), dimanfaatkan oleh $V$. harveyi, karena ternyata $V$. harveyi mampu memanfaatkan L-prolin (Bergey's Manual, 2005), sehingga tepung cacing tanah ( $L$. rubellus) tidak mampu menghambat pertumbuhan bakteri V.harveyi.

Selain kedua dugaan tersebut, terdapat dugaan lain yang menyebabkan tepung cacing tanah (L. rubellus) tidak mampu menghambat pertumbuhan bakteri $V$. harveyi secara in vitro, yaitu disebabkan muatan positif total dari lumbricin hanya +1 (Cho et al., 1998). $V$. harveyi, sebagai bakteri Gram negatif, memiliki lapisan dalam yang tersusun atas peptidoglikan yang tipis, sedangkan membran terluar disusun oleh peptidoglikan yang tebal, sehingga membran sel bakteri bermuatan negatif. Sedangkan kationisitas (tingkat muatan positif) tidak diragukan lagi merupakan faktor yang penting untuk daya tarik elektrostatika awal peptida antimikroba terhadap muatan negatif membran fosfolipid bakteri (Yeaman and Yount, 2003). Mekanisme kerja peptida antimikroba diawali dengan interaksi awal antara peptida antimikroba dengan sel target 
(bakteri) akibat pengaruh daya elektrostatika (Yeaman and Yount, 2003). Terdapat hubungan yang kuat antara tingkat kationisitas peptida antimikroba dengan aktivitas antimikroba (Besalle et al., 1992; Matsuzaki et al., 1996 dan Dathe et al., 1997 dalam Yeaman and Yount, 2003), dimana secara umum, dengan meningkatnya kationisitas maka aktivitas antimikroba juga meningkat (Dathe et al., 1997 dalam Yeaman and Yount, 2003). Dalam penelitian yang lain, yang menguji daya antibakteri beberapa peptida antimikroba sintetis terhadap $V$. harveyi, diketahui bahwa peptida antimikroba sintesis tersebut, yang total muatan positifnya bervariasi antara +3 hingga +6 , ternyata mempunyai daya antibakteri terhadap V. harveyi (Chou et al., 2008). Sehingga dengan demikian, karena muatan positif total lumbricin hanya +1 , sedangkan membran sel bakteri $V$. harveyi bermuatan negatif, maka lumbricin tidak mampu melakukan interaksi awal melalui daya elektrostatika, sehingga mekanisme kerja selanjutnya yang dapat mengakibatkan kerusakan pada membran sel bakteri tidak dapat terjadi, sehingga lumbricin dalam tepung cacing tanah (L. rubellus) tidak mampu menghambat pertumbuhan bakteri $V$. harveyi.

\section{Kesimpulan}

Dari penelitian ini dapat disimpulkan bahwa tepung cacing tanah (L. rubellus) tidak dapat menghambat pertumbuhan bakteri $V$. harveyi secara in vitro. Sehingga disarankan untuk tidak menggunakan tepung cacing tanah sebagai salah satu cara pengobatan vibriosis. Selanjutnya dapat dilakukan penelitian lanjutan untuk mengetahui faktor yang menyebabkan tepung cacing tanah (L. rubellus) tidak dapat menghambat pertumbuhan bakteri $V$. harveyi.

\section{Daftar Pustaka}

Adam, M. 2007. Pengaruh Pengobatan Ikan Lele Dumbo (Clarias gariepinus) yang Terinfeksi Bakteri Aeromonas hydrophila dengan Menggunakan Ekstrak Cacing Tanah (Lumbricus rubellus). Jurusan Manajemen Sumberdaya Perairan. Fakultas Perikanan. Universitas Brawijaya. Malang 95 hal

Asfanti, M.I. 2008. Pengaruh Pemberian Tepung Cacing Tanah (Lumbricus rubellus) terhadap Kekebalan Tubuh Ikan Mas (Cyprinus carpio). Fakultas Perikanan dan Ilmu Kelautan. Universitas Brawijaya. Malang
Bergey. 2005. Manual of Systematic Bacteriology. $2^{\text {nd }}$ Edition. Volume 2. Part B. Proteobacteria. Gammaproteobacteria. Pp 524-525.

Cho, J. H., C. B. Park, Y. G. Yoon and S. C. Kim. 1998. Lumbricin I, a novel prolinerich antimicrobial peptide from the earthworm: purification, cDNA cloning and molecular characterization. Biochim Biopys Acta. 1408: 67-76.

Chou, H., Kuo, T., Chiang, J., Pei, M., Yang, W., Yu, H., Lin, S., and Chen, W. 2008. Design and synthesis of cationic antimicrobial peptides with improved activity and selectivity against Vibrio spp. International Journal of Antimicrobial Agents 32: 130-138.

Damayanti, E., A. Sofyan, H. Julendra dan T. Untari. 2009. Pemanfaatan Tepung Cacing Tanah (Lumbricus rubellus) sebagai Agensia Anti-Pullorum dalam Imbuhan Pakan Ayam Broiler. Jurnal Ilmu Ternak Veteriner 14(2): 83-89.

Departemen Kesehatan Republik Indonesia. 1995. Farmakope Indonesia. Edisi 4. Kadar Larutan. Hal 1.

Dewi, F. K. 2010. Aktivitas Antibakteri Ekstrak Etanol Buah Mengkudu (Morinda citrifolia L.) Terhadap Bakteri Pembusuk Daging Segar. Jurusan Biologi. Fakultas Matematika dan Ilmu Pengetahuan Alam. Universitas Sebelas Maret. Surakarta. 38 hal.

Gold Biotechnology. 2009. Material Safety Data Sheet: D-Proline. 4 pp.

Izzati, M. 2007. Skreening Potensi Antibakteri pada Beberapa Spesies Rumput Laut terhadap Bakteri Patogen pada Udang Windu. Bioma. IX (2) : 62-67.

Julendra, H. 2003. Uji Aktivitas Antibakteri dari Cacing Tanah (Lumbricus terestris) sebagai Bahan Pakan Ayam terhadap Pertumbuhan Bakteri Salmonella pullorum secara In Vitro. 9 hal.

Julendra, H. 2005. Pengaruh Penambahan Tepung Cacing Tanah (L. rubellus) sebagai Suplemen Pakan terhadap Aktivitas Salmonella pullorum dengan Uji secara In Vitro. 7 hal.

Julendra, H dan A. Sofyan. 2007. Uji In Vitro Penghambatan Aktivitas Escherichia coli dengan Tepung Cacing Tanah (Lumbricus rubellus). Media Peternakan 30 (1): 1-7.

Maryani, D. Dana, dan Sukenda. 2002. Peranan Ekstrak Kelopak dan Buah Mangrove Sonneratia caseolaris (L) terhadap Infeksi Bakteri Vibrio harveyi pada 
Udang Windu (Penaeus monodon Fab.). Akuakultur Indonesia I (3) : 129-138.

Palungkun, R. 2008. Sukses Beternak Cacing Tanah Lumbricus rubellus. Penebar Swadaya. Jakarta. hal. 5-15.

Prayitno, A. 2007. Uji Sensitifitas Flavonoid Rumput Laut (Eucheuma cottoni) Sebagai Bioaktif Alami Terhadap Bakteri Vibrio Harveyi. Jurnal Protein 15 (2) : 66-71.

Purwaningrrom, D.L. 2010. Uji In Vitro Pengaruh Jenis Tepung Cacing Tanah (Lumbricus rubellus dan Pheretima aspergillum) dengan Variasi Suhu Pengolahan $\left(50^{\circ}, 60^{\circ}\right.$ dan $\left.70^{\circ}\right)$ terhadap Penghambatan Pertumbuhan Bakteri Salmonella thypi. Fakultas Ilmu Biologi. Universitas Islam Negeri Maulana Malik Ibrahim. Malang. 98 hal.

Quelab. 2005. Mc Farland Standard. Diakses melalui http:/www.quelab/htmleng/ 2900a/html pada 10 Oktober 2011.

Rattanachuay, P., D. Kantachote, M. Tantirungkij, T. Nitoda and H. Kanzaki. 2010. Inhibition of Shrimp Pathogenic Vibrios by Extracellular Compounds from a Proteolytic Bacterium Pseudomonas sp. W3. Journal of Biotechnology 13(1) : 1-11.

Rukyani, A. 1999. Beberapa Jenis Penyakit Sebagai Kendala Utama Budidaya Udang dan Cara Pengendaliannya. Badan Litbang Pertanian.

Sarkar, S., A. Pramanik, A. Mitra, J. Mukherjee. 2010. Bioprocessing Data for the Production of Marine Enzymes. Marine Drugs ISSN 1660-3397: 1323-1371.
Saulnier, D., H. Philipe., G. Cyrille., L. Peva and A. Dominique. 2000. Experimental Infection Models for Shrimp vibriosis studies: a review . Aquaculture, 191 : 133-144.

Uma, A., K. Saravanabava, R. Singaravel and A. Koteeswaran. 2005. Antibiotic Resistant Vibrio harveyi Isolated from Swollen Hindgut Syndrome (SHG) Affected Penaeud monodon Post Larcae from Commercial Shrimp hatcheries. Tamilnadu Veterinary and Animal Sciences University, Madhavaram Milk Colony, Chennai. 4 pp.

Umar. 2009. Potensi Isolat Bacillus sp. Lts 40 menghambat pertumbuhan Vibrio harveyii penyebab vibriosis dan meningkatkan sentasan udang windu (Penaeus monodon Fab.) Institut Pertanian Bogor. Bogor. hal 20-23.

Whitelock, J.M., Murdoch, A.D., Iozzo, R.V., Underwood, P.A. 1996. The Degradation of Human Endothelial Cell-derived Perlecan and Release of Bound Basic Fibroblast Growth Factor by Stromelysin, Collagenase, Plasmin, and Heparanases", Journal of Biological Chemistry 271 (17): 10079-10086.

Windyaanita, H. 2006. Daya Antibakteri Buah Mengkudu (Morinda citrifolia L.) yang Diekstraksi dengan Etanol dan yang Diekstraksi dengan Air Terhadap Aeromonas hydrophilla Secara In Vitro. Universitas Airlangga Surabaya. 57 hal.

Yeaman, M. R. and Yount, N. Y. 2003. Mechanisms of Antimicrobial Peptide Action and Resistance. Pharmacological Reviews 55 (1) : 27-55. 